\title{
FRENCH MEMORICIDES IN ALGERIA: A STUDY ON SOCIALIZATION INSTITUTIONS
}

\author{
Delliou Foudil ${ }^{* 1}$ 不 \\ ${ }^{* 1}$ University of Constantine 3, Algeria
}

DOI: https://doi.org/10.29121/granthaalayah.v8.i7.2020.729

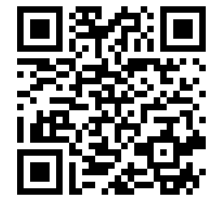

\section{Article Type: Case Study}

Article Citation: Delliou Foudil. (2020). FRENCH MEMORICIDES IN ALGERIA: A STUDY ON SOCIALIZATION INSTITUTIONS. International Journal of Research GRANTHAALAYAH, 8(7), 340-353. https://doi.org/10.29121/granthaa layah.v8.i7.2020.729

Received Date: 13 July 2020

Accepted Date: 31 July 2020

Keywords:

French Memoricides

Algeria

Socialization Institutions

\section{ABSTRACT}

The French occupation of Algeria was a colonial as well as a cultural one, during which many criminal practices were committed against the Algerians. This work aims to highlight some of these practices, which undoubtedly amount to war crimes of cultural genocide against all types of Algerian socialization institutions: religious, educational, media, sports, charitable ones ... We will try to present some edifying samples of these institutions after a brief preamble about the Algerian socialization system, and how French military and colonists deal with this system through philosophical premises and practical procedures. Finally we will end the work by citing some reactions of Algerian resistant reactions to these criminal practices.

\section{INTRODUCTION}

The French occupation of Algeria (1830-1962) was a settlement and a cultural occupation with a hostile perspective whose background may be traced back to the Crusades, and for that purpose it committed many crimes, which have had the most severe and widespread effects on Algerian generations. These crimes can certainly be qualified as systematic cultural genocide against the Algerian civilization. Indeed, the French soldiers endeavored to denigrate Islam and the Arabic language, as well as weaken the Algerian communication system, try to obliterate their cultural identity and erase their collective memory, in order to allow Europeans in general and the French in particular to subdue the "indigenous" inhabitants and occupy their land.

In order to reach this objective, the French occupier did not hesitate to attack the insubordinate social institutions by demolishing, burning, looting and robbing them; as well as threatening, imprisoning, exiling and murdering their managers. All that happened, despite France's official commitment in the fifth clause of the conditional surrender treaty which it signed with the "Dey" of Algeria on July the $4^{\text {th }} 1830$, which stipulated that "the practice of the Mohammedan religion will remain free; the freedom of the inhabitants of all classes, their religion, their trade and their industry will not be affected; their wives will be respected " (Galibert, 2012) ${ }^{1}$; and in spite of Governor General (Pélissier) pledge that "the traditions of the Algerians will be respected and not a single soldier will enter the mosques" (Lahmar, 2011, p. 11). 
This work aims to expose some of these acts, which undoubtedly amount to war crimes against the identity and memory of Algerians, and all their social communication supports, such as the press and journalists, educational institutions and teachers, intellectual and sports clubs, mosques and Zaouaias, libraries and theater fairs (Karagöz puppets, performances of praisers/"Al-Maddahin"...)... and their vital funding pillars: Awqaf (endowments) and printing houses... Consequently, memory crimes (Memoricides) here include broader communication institutions and activities than those usually defined by "information sciences" as museums, libraries and archive centers.

And if international norms and laws issued by international organizations unanimously agreed that the systematic and deliberate destruction of libraries and archives is considered as a crime against humanity in the international humanitarian law and according to Geneva (1949) and Hague (1954) Conventions (Blazina, 1996, pp. 149-164), so what about all the aforementioned crimes?

We will try to display samples in their different specifications with some of the theoretical premises and practical consequences, by presenting the following elements:

1) Socialization institutions after the French occupation.

2) How the French occupier dealt with these institutions: their philosophical premises and practical procedures.

3) The Algerian reaction.

\section{SOCIALIZATION INSTITUTIONS AFTER THE FRENCH OCCUPATION}

Algeria was characterized by its social communication network with spiritual and symbolic manifestations based on Sufi (brotherhoods) and Almoravid Islam² which are deeply rooted in daily life (Boyer, 1960, p. 54). After the French occupation, cultural life in Algeria was generally focused on several communication institutions (cultural, educational, media ones...), the most important of which are: mosques, prayer sites (Jama'a), Zaouaias (Sufi's religious institutions), schools "Medersas", libraries, popular gatherings, temporary parties (for memorizing, chanting, storytelling, playing...), theaters of the Karagöz puppets (like Chinese shadow), praisers, and performers (To warn off risks and give orders) and debate forums...

The main vehicle of this communication system was the Arabic language, while the largest institution that nurtured most of these institutions with their various activities (worship, education, "Ribat", residence, and entertainment) was the "Endowments (Waqf/ Habous) Foundation" (Saadallah, 1998, pp. 159-161, 227).

In quantitative terms, the number's estimate of these institutions varies according to different sources:

- With regard to religious institutions, Devoulx and Aumerat (Devoulx, 1862, p. 372; Aumerat, 1898, p. 178) said that, after the occupation, the city of Algiers had 176 religious institutions (122 mosques, 44 Zaouaias, and religious shrines), While the French Ministry of War estimated them at about 150 institutions (including 106 jama'a and mosques ...), and in the city of Constantine, there were 75 high schools and mosques in a record for its governor "Salah Bey", and in Tlemcen 50, Annaba 37, etc. (Saadallah, 1998, Pp. 176, 248-250).

- Concerning primary, secondary and high schools, which were mostly attached to mosques, "Jawami'a" and zaouaias, they were spread in the most important Algerian cities: Algiers (100 primary and secondary schools), Constantine (90 primary schools and 07 secondary and higher Schools), Tlemcen (50 primary schools and 5 Secondary and higher Schools) ... (Saadallah, 1998, pp. 274-276; Chitour, 1999, p. 128).

- Other references (Djeghloul, 1982, p. 93) state that the percentage of male Algerians who knew how to write and read (literate) was about $40 \%$ of the population.

- As for the libraries, there were many public (attached to mosques, "Rabitat", and schools, most of which were suspended) and private ones. This private one were the biggest in number (belonging to families and religious figures: Al-Fegoun, Bachtarzi, Al-Ouartilani ...) (Saadallah, 1998, pp. 296-308).

- Performances and parties were occasional and periodic: Prophet's birthday celebration, the two principal religious feasts "Al-Aidein", farwell and receiving pilgrims, return from wars, marriages ..., and they included concerts, chants, performances of the Karagöz puppets and praise.

- Regarding to publishing establishments (books, newspapers...), there were some people working in the book industry in Algeria, including paper mill, binding, copying and calligraphy. Among the most 
important cities that were famous for this: Tlemcen, Mascara, Constantine, Bejaia, Algiers, and Beni Yazguen (M'zab) (Saadallah, 1998, pp. 285-309).

After the improvement of printing techniques and the spread of the phenomenon of newspapers, the Algerians used to use French presses inlaid with Arabic letters and then they created their own Arab printing presses to overcome the hassles of traditional stone presses and get rid of dependency on the French. Some Algerians established several presses in Algiers, Constantine, Mostaganem, Oran and Biskra in order to publish their newspapers and books. The most important ones were: the "Algerian Islamic printing" of Benbadis and the printing of "An-Najah" (1919) in Constantine; the "North-African printing"of Sadiq Denden and his partners (in Algiers), "AlIqdam printing" (1923); the "Arab printing" of Abu Al-Yaqdhan in Algiers (1926); "Al-Balagh printing"of Zaouia"AlAliouia" in Mostaganem and then in Algiers; the "Scientific printing" of Tayeb al-Oqbi (1929) in Biskra; the "Maghreb printing" of Hamza Boukoucha in Oran (1937); "Al-Bassair printing" of the Association of Ulama (1954), which the French "Secret Army" (OAS) destroyed the day after independence, because of its cooperation with the National Liberation Front... (Saadallah, 1998; Lahmar, 2010; Montoy, 1982)3.

\section{COLONIAL PHILOSOPHICAL POSTULATES AND PRACTICAL PROCEDURES AGAINST THE ALGERIAN COMMUNICATIVE SYSTEM}

\subsection{JUSTIFICATORY PHILOSOPHY}

The occupation's justification had a philosophy that was represented by the discourse of the invading dominant ideology, which was hidden behind concepts that spread among the "people" and part of the settlers to adopt and represent the following three binaries that Lycops (1975) explained in his book entitled: "Silent aggression or cultural genocide in Africa":

1) Describing the "Indigenous" people as religiously guilty in exchange for offering to save their lives in a Christian way.

2) Describing the "Indigenous" people as brutal and uncivilized in exchange for offering them French civilization by changing their history, language and religion.

The French king Charles X, prior to the invasion of Algeria, mixed the previous two indicators, where he said: "France wants to civilize the Africans by Christianizing them" (Chetouane, 2005, p. 393).

3) Describing the "Indigenous" people as underdeveloped and poor in exchange for offering them development and financial enrichment through exploiting their natural resources.

In the name of this philosophy, several cultural genocide crimes have been committed. What are the techniques and procedures used to achieve this? And what are the most important factual manifestations -represented by social institutions and their managers- committed in the name of this philosophy?

\subsection{PSYCHOLOGICAL TECHNIQUES}

The occupation relied, in the implementation of its crimes, upon several psychological techniques in order to achieve subjugation and blind imitation of the native people:

- Intimidation, terror and psychological subjugation by focusing on the effect of "military defeat", presence of the armed forces, and material welfare.

- Implantation of a psychological deficiency complex (creating a complex of inferiority and lower rank) by encouraging controlled elite visits and allowing immigration to France, creating impressive modern economic spaces, using modern agricultural industry techniques, and publicizing that themselves or through educated or charlatan local agents.

- Oriented integration: through selective and limited education for natives; naturalization and christianization; oriented, conditional and limited councils representation and remunerated employment - at a minimum or in the form of material compensation - for administrative, religious, and service intermediaries ... 
French Memoricides in Algeria: A Study on Socialization Institutions

- Relating this integration to a "glorious" Christian-Latin "nostalgia" that the France of the past "Gauls" will relate "Indigenous" with it.

\subsection{LEGAL PROCEDURES}

The successive political regims in Paris (royal monarchy of July, second republic -1848-, third empire -1851- ...) practiced repressive legislation which limited freedom of the press and associations, the use of the Arabic language and the Islamic judiciary system; and controlled the creation of printing houses, libraries and preaching in mosques

$\ldots$

This began with the Ministerial Decree ("Arrêté") of 2/8/1836, which placed the press under the authority of the French Governor-General, authorizing him to supervise the use of the press, license or prohibit any publication, and grant licenses to printers and libraries" (Montoy, 1982, p. 5). It was followed by several consecutive repressive legislative measures (Decrees of 1848 and 1849, and Law of 1850) to again hinder journalistic activity (Seif al-Islam Zoubir, 1982, p. 30; Montoy, 1982, p. 6). Until the law of 1881 on freedom of the press, only "French" newspapers were freed from most of the legal barriers, because the Article 14, which considered non-French newspapers in Algeria as foreign newspapers, was later used (Law: 7/28/1885) to harass and suppress Arabic-language newspapers published in Algeria. Indeed, Algerian newspapers suffered racial discrimination, psychological persecution, and administrative and security oppression (Delliou, 2014, p. 129).

The occupation authorities have resorted to defrauding the general law, as what happened with the failure to grant the Algerians the right to vote to elect the local councils (complete deprivation and then a relative and discriminatory permission), or with their non-application of the "separation of church and state" (law of 1905).This law applied to the five religions in Algeria recognized by France - Catholic, Judaism, Lutheran, Calvinist and Islam and it should be applied in Algeria thanks to the decree of September 27, 1907. But the occupation authorities imposed double standards and overrided the logic of occupation over secular discourse in the case of the Islamic religion alone, in order to control its followers by legalizing their administrative dependency and not allowing them to form "free" cultural associations that manage their institutions, like other representatives of other religions, and resorted to this, by extending the actual application -in a disguised way- of the "Governor General's Circular for 1851" and by activating the work of the Committee to manage and monitor mosques approved since 1870 without any Legal text (Saaidia, 2016, pp. 5-8).

The main language support and medium of this communicative system was the Arabic language, which made the occupier's plan to impose French linguistic dominance supported by a local linguistic division policy. For him, Arabic -according to one of his generals (Lyautey)- is an element of unity and Islamization, as it is taught by the Qur'an, and that the interest of the occupier forces him to make "Berbers" develop outside the framework of Islam which requires, from a linguistic perspective, to tend to pass directly from Berbers language to French (Benbennadji, 2019, p. 196), and from a religious perspective, to bring Berbers back into the arms of the Gospel and Latin civilization after 15 centuries of absence, as the French orientalist officer "Marty" said (Pelligrin, 2011), thus breaking the cultural, linguistic and religious solidarity that exists between Arabs and Berbers. Language policy in Africa in general is for the occupant - whatever his nationality - Machiavellian. For example, the linguistic policy of the British occupation supported the Arabic language in Eritrea, while it banned it in South Sudan where it supported the Triad of the occupant language, the African languages and Christianity for separatist purposes, and it also weakened classical Arabic by trying to write it in Roman letters and encouraging vernacular dialects (Benbennadji, 2019, pp. 201, 211). The same Triad was supported by the French occupier in the Algerian Kabylie region: the French and "Berber" languages and Christianity, in addition to the same hostile policy approach toward the Arabic language.

\subsection{PRACTICAL PROCEDURES}

The Algerian writer and poet Moufdi Zakaria (2003, p. 32) summarized the occupation methods, used to subject the Algerian people to "the fait accompli", in the triptych "sword, plow and cross", which can be made quadruple by adding the "tongue" (preaches, media, and education). While Saaidia (2016, pp. 3, 4) believes that the French military authorities considered that controlling the Algerian people would only be achieved through the control of Islam - as being the most important obstacle to the occupation - so the first measure to implement this trend was the seizure of movable and immovable endowment properties (Waqf/ Habus) which have multiple functions such as 


\section{Delliou Foudil}

maintaining mosques, teaching children, providing for the needy ... with control over their representatives because they believed that depriving Islam of its endowment financial pillar will automatically lessen its dangerousness. This juridical control was practiced since 1835, after inciting to file a complaint against the endowment agents to facilitate its official intervention. Then this control was generalized over the rest of the charitable institutions: "Bayt al-mal" (treasury), "Souboul Al-Kheirat" (Paths of good deeds), associations of Andalusians ... All of these institutions (especially in the cities) were included within the endowments and put under their control in the mid-forties.

Corruption, plundering and looting managed by the French administrators, the seizure of endowment properties and the placing of the religious institutions and their administrative representatives under military and political authorities, could only facilitate the framing of part of Islamic practices, but not ensure the control of the religiosity of society. This has led to the emergence of an alternative religious discourse, in Constantine for example, through Sheikh Benbadis activities and a remarkable growth in the number of free mosques.

In practical terms, the occupation authorities have not waited to tighten their control over religious institutions and the rest of the socialization institutions as they began committing their crimes since the first days of the occupation:

Since then, their military authorities have rushed to demolish and / or convert mosques, "Zaouaias", domes, cemeteries, schools and social shelters into: military barracks, weapons and torture warehouses, temporary military hospitals, soldiers' stalls, horse stables, churches and nunneries, government headquarters, commercial bazaars, theaters, French baths, secondary schools, private residences... (Aumerat, 1898, pp. 174-196). Here are realistic examples of this:

\subsubsection{MOSQUES AND ZAOUAIAS}

Some of them demolished and converted to horse stalls, soldiers' stalls, and field hospitals, then later, to Christian societies' establishments and to monasteries and churches; others were sold to French settlers to demolish them and build in their place homes, baths, bakeries, shops, stores, animal pens, theaters ...; others were vandalized and demolished by defiance (Aumerat, 1898, pp. 168-201); and some others were preserved with the seizure of their endowments, offending them, and exiling their imams or subjugating them... like the Great Mosque (Al-jama'a AlKebir) (Saadallah, 1998, pp. 10,12). In addition, support was given to building new Christian churches, in addition to respecting the Jewish synagogues and encouraging their construction in the context of the Christianization policy and supporting the Jewish presence in Algeria. The repercussions of that, and according to some French people who wrote especially in the official African magazine (Revue Africaine) and in others reviews were:

Laborde (20/8/2010) indicated that the number of mosques decreased between 1830 and 1862 from 103 to 47 , instead of increasing in number according to the natural demographic growth of Muslims. While other French references (Devoulx, 1862, p. 372) indicated that there were about 176 religious buildings or religious monuments, including 122 mosques in Algiers (under occupation), of which, according to "Devoulx" himself in 1862 there remained twelve mosques, whose number decreased to only six metropolitan mosques in 1898, according to "Aumerat" (1898, p. 187). The most important ones are the "Hanafi" New Mosque, the Grand Mosque - with a confiscated Zaouia - and the "Ballots" Mosquee (Saadallah, 1998, p. 12, 72).

Some examples until 1897 (Aumerat, 1898, pp. 178-196):

In 1830, French occupation launched its first attacks on mosques by demolishing one of the seven major metropolitan mosques, the "Mosque of Al-sayyida" (Some of its buried ruins were discovered recently when the metro was built in Algiers) and replacing it with a military building. It was followed by the disposal of other mosques of great scientific fame and value such as the mosques: Abdi Pasha, Hussein Mezzo Morto and Khader Pasha... and second-class mosques such as the Muhammad Pasha Mosque and the Andalusian Ibn Negro Mosque (demolished in 1837) and the "Sidi Al Rahbi" Mosque (1840) which was converted to a pharmacy...

In 1831, the "Al-Qashash" Mosque was converted into soldiers' shelters, then into a central warehouse of hospitals, then into a school of arts and in 1841, the Zaouia of the Algerian Andalusian people located in the Kasbah neighborhood of "Zankat al-Zibdeh" was demolished. As for the famous capital "Ketchaoua" (Keçiaawa/ آوى ) mosque, was converted at the end of 1832 to the church "Saint Philippe" after killing at least 309 worshipers among the nearly 4000 who held a sit-in protesting against the decision to storm it on 18/12/1831 (Rahal, 2018) ${ }^{4}$. Then the occupier promoted it to the Cathedral of Notre Dame of Algeria from 1845 to 1860. In April 1834, French authorities (according to the deputy in the French Parliament: De Sade) seized sixty mosques to be placed at the disposal of the 
French Memoricides in Algeria: A Study on Socialization Institutions

army, demolished ten of them, and turned some of them into churches, as happened with the "Casbah" mosque in 1839, which was converted into the Saint Croix Church and the mosque "Ali Betchin" to the church "Notre Dame des Victoires" in 1843, and before that the Mosque of Al-Kaid Ali, which was converted in 1842 to an annex to the Monastery of the Sisters of Saint Joseph (1836) ... Some others to "weapons and torture warehouses" such as the Kouchet Ben Al-Samman Mosque, or to French baths such as the Zaouia of the Great Mosque in 1833 (Aumerat, 1898, pp. 183-191).

Mosques, Zaouaias and domes continued to be demolished inside and around Algiers, Among those which suffered demolition and "militarization" were: the Zaouia of Sidi Ya'qub with a dome and a cemetery, the mosque of Muhammad Pasha, the Zaouia of Sidi Ammar al-Tenisi (demolished in 1861), the Zaouia of Sidi Abdel-Rahman alTha'alabi with a mosque, dome, and dormitories, attached to the administration at the end of 1848... (Aumerat, 1898, pp. 191-192).

This demolition, vandalism, and neutralization affected such religious and social institutions present outside the capital, in particular in the two other important regions of Algeria: Oran (with 148 mosques), and especially Constantine (with 837 mosques), which was known for the religiosity of its inhabitants, who -for that reason- had suffered greatly from the French abuse as well as the seizure of their religious buildings, and their endowments (Waqf) after its occupation in 1837. They took the initiative to neutralize the central "Rahbat al-Souf" mosque and make it a military storehouse of barley, and then to overthrow its minaret in 1852, as well as to convert the "Kasbah Mosque" into a military building, and the Al-Ghazal Mosque to a cathedral in 1839 ... (Saadallah, 1998, pp. 80-83). Feraud (1868) also referred to the demolition of seven mosques in Constantine in 1868 with the conversion of "Jama'a El Bey" to a church and another one to a field hospital...Other cities have not escaped the policy of seizure of endowment properties and the demolition of mosques, like Annaba, where only three mosques from its 37 mosques were spared in 1889; and some of them were converted into churches, like what happened with the Benmerouan Mosque (Annaba) and Benamer Mosque (Al-Barraniya) in Oran, which was transformed into the "Saint Andre" church in 1850 (Saadallah, 1998, pp. 92-93, 102; Chetouan, 2005, p. 396).

Faced to this widespread demolition and sabotage, some of the Almoravid successors sold some of their Zaouia to the settlers (such as the Zaouia of Almoravid Abbasi in Algiers, and others colluded with the occupier who expanded their Zaouia and put them at his disposal, such as that of Sidi Muhammad al-Sherif Zaouia (Aumerat, 1898, pp. 190). Some mosques outside the capital were also converted into military barracks (the Kasbah Mosque in Bejaia), and to stores, shops, and pig breeders, which were handed over to Jewish merchants: the Sidi Hassan Mosque in Mascara, and the "khanq Ennitah" Mosque in Oran ... (Chetouane, 2005, 396).

\subsubsection{DOMES AND CEMETERIES}

Colonization desecrated and demolished domes and cemeteries before converting them into squares, stables for horses and educational institutions for Europeans settlers; in addition to that it sells some of them to Europeans who wanted to build private housing. We can give some examples as: the demolition of the public cemetery of Zaouia Sidi Al-Joudi (in 1830), the conversion of the Zaouia cemetery of Sidi Ahmed ben Abdullah to a cooperative school, and the conversion of most of the private cemeteries attached to the Zaouaias (cemeteries of Hassan Pasha, Hajji Pasha, Sidi al-Jama'a and al-Kattani ...) to military services (Aumerat , 1898, pp. 189-194). Thus, French authorities eliminated some spaces of spiritual and social communication, especially since most of them were subordinate to the Zaouaias and were regularly the subject of religious visits.

\subsubsection{EDUCATIONAL SYSTEM}

It was clear through what preceeds that colonization aimed to destroy educational system and to weaken its material and social it was decided to destroy foundations; by seizing "endowment" and "private" properties in various ways: purchase, confiscation, nationalization, taxes, usurious speculation - especially by Jewish - mortgage, brokering ... especially in the period of famines. In this context, General Bertrand Clauzel issued a law on December 7,1830 requiring the transfer of all endowment funds to state ownership on the pretext that it was not possible to leave loose funds in the hands of religious societies that may transfer them into the hands of "terrorists" to be used against the French occupation (Lahmar, 2010, p. 164), and in 1836 the occupation authorities dissolved the institution overseeing the endowments of the Andalusians (Saidouni, 2003, p. 90). 
And just as it closed and demolished mosques and Zaouaias, colonialism played the same role towards institutions of religious and public education. Some examples of them are in the capital: the demolition of the Khair al-Din school, the M'sid internal school and the Al Rahba school. French and Algerian historical sources indicate a significant drop in education in the big cities (Algiers, Constantine, Annaba, Oran ...), where Algerian education has become scarce due to demolition and closure - indicated above - as well as its subjection to the law of foreign schools and the persecution and migration of scholars and teachers (Chetouan, 2005, pp. 403-404).

\subsubsection{LIBRARIES}

Public libraries -attached to mosques, Zaouaias and schools and which most of them were endowments- were looted and burned, as well as private libraries, which were the most numerous (belonging to families and religious figures: Al-Fegoun, Bechtarzi, Al-Ouartilani...). Their owners were deported and exiled, and some of their books were confiscated, the rest was transferred by some French soldiers and settlers to their libraries in France. This cultural bleeding has increased the risk of displacement of the great scholars and the rich with their books and manuscripts in the case that they were not burned or confiscated. And according to Polastron (2004, p. 15), France was famous for having looted precious books from several regions: Vietnam, China, Egypt, Spain, Italy, North Africa ... which should one day be returned.

Later, some national and regional French libraries were gradually installed in their place, mainly for providing an invasive and distorting French culture of Algerian history and civilization.

It should be noted here that the "natives" (the Algerians) did not benefit from the educational books (for schools or universities) for discriminatory, racial or objective linguistic and cultural reasons, and some of them were burned down during the last years of the liberation war so that the Algerians would not benefit from them after the departure of the occupier, what actually happened to the university's library in Algiers that was burned on June the 7th, 1962 by the French "Secret Army Organization" (OAS) -which was opposed to the independence of Algeria-, where about 600 thousand books were destroyed. (Zaoui, 14 juin 2012).

\subsubsection{ISLAMIC JUDICIARY SYSTEM}

French authorities used to demolish Islamic judiciary system gradually, as the occupation authorities issued on February 28, 1841 a law abolishing the authority of Muslim judges.

At that time French authorities started approving the application of the French penal code on Algerians, and then ending the stage of self-management of the Islamic judiciary allocated to the people (starting in the year 1870), which lasted 22 years (since about 1848) and the inauguration of the phase of reducing the powers, legislations, provisions and number of Islamic judiciary officials, this stage lasted 21 years (until 1891) (Saadallah, 1998, p. 77).

\subsubsection{REFORMIST AND POLITICAL PRESS}

Their activities were restricted and repressed to prevent its contribution to revive the Algerians memory, in various illegal and discriminatory legal ways, by considering for example non-French-speaking language newspapers in Algeria as foreign newspapers. Indeed, Algerian newspapers have suffered such an administrative and security repression, since as soon as a journal issue was published, the occupation authorities (the Ministry of Interior or the Governor-General) would take the initiative to seize it. This happened if it permitted its issuance at all. Its staff also suffered threats, trials, imprisonment, exile and assassination:

French authorities tried the artist and journalist Omar Racim (the owner of the newspaper "Algeria": 1908, and "Zulfikar": 1913) in a military court and imposed a sentence of life imprisonment with forced labor (1915-1921), which is, in our opinion, the most severe sentence imposed on a journalist at that time in the world. They then banished Emir Khaled (editor-in-chief of "Al-Iqdam" newspaper: 1919) in 1923 until his death in 1937. They imprisoned and exiled Sheikh and journalist Muhammad Lamine al-'Amoudi in the beginning of the 1930s (owner of the two weekly newspapers "La Défense": 1934 and "Le Musulman"), as they attempted assassination of Sheikh Abdelhamid Benbadis (pioneer of the reformist press) and then assassinated Sheikh Larbi Al-Tebessi (first editorin-chief of "Al-Bassa'ir": 1935 and "Le Jeune Musulman" newspapers: 1952...), considering him an Algerian journalist 
French Memoricides in Algeria: A Study on Socialization Institutions

whose pen called for rebellion against the French. He is, according to our knowledge, the first journalist in the world who was killed, his body was hidden, and whose burial place is not yet known.

In 1962, and in the same context, the New "Al-Bassa'ir" Printing, owned by the Association of Algerian Muslim Ulema', was bombed by the French "Secret Army Organization" (OAS), which was against the independence of Algeria (Saadallah, 1998; Lahmar, 2010).

\subsubsection{CHARITABLE INSTITUTIONS AND SHELTERS}

They were not spared also from aggressions: as an example we can cite the conversion of the shelter "Boutouil" intended for the poor, orphans, disabled, sick and simple workers, in a military barrack in 1830 (Aumerat, 1898, p. 196).

\subsubsection{KARAGÖZ PUPPETS AND MEDDAHIN (PRAISERS)}

Their spectacles were banned in public squares and cafes, to prevent them from sparking patriotism among the Algerians, and to deprive the public of a social entertainment tool.

Adding to all this sabotage and criminal "emptying" policy, a strategic "filling" one has been followed by:

\subsubsection{SETTING UP OF CAFES OF MUSIC AND DANCE AND PROSTITUTION PREMISES}

They were established in major Algerian cities: Constantine, Annaba, Oran and especially in Algiers the capital, some of which were close to worship places (Saadallah, 1998, p. 440). by defiance and entertainment.

\subsubsection{CONSTRUCTING SEVERAL CHURCHES AND SOME SYNAGOGUES}

The two churches of "St. Augustin", the first between 1847 -1865, and the second between 1876-1878, "Notre Dame d'Afrique" church between 1858 -1872 which was expanded twice (1928 and 1947), the church of "St. Bonne Venture" in 1870, the "New Anglican" church in 1909, the church of Kouba (1923), "St. Anne" church (1931) 1933), and the "Sacred Heart of Jesus" church (Le Sacré Coeur) (1956-1961)...

Some synagogues that were added to about ten others that were distributed over the major coastal cities were they're built: a synagogue with harmonium between 1855 and 1865, and the Grande Synagogue built in 1878 (Laborde, 20/8/2010).

\subsubsection{SUPPORTING MILITARY CAMPAIGNS WITH CATHOLIC MISSIONARY}

This occurred from the very first moment, when sixteen priests accompanied the military campaign to occupy Algeria (1832) for the purpose of Christianizing the Algerians (Chetouan, 2005, p. 392). Noting that the missionary campaigns focused on the Kabylie region (for strategic division purposes), then in all coastal cities, and they moved them later (after 1872) to the south (Hoggar region) under the leadership of the priest De Foucault. Some other European missionary campaigns (Switzerland, Germany ...), especially Protestant ones were also launched (Boyer, 1960, 366-367).

This is in addition to fighting Zaouaias's activities in Kabylie region, they prohibited Muslim religious jurists from moving there, and fought speaking other than Berber and French languages (Al-Hossari, 1951, p. 476). This combined religious and linguistic discrimination in this region has had known effects on the future social, cultural and political structures of contemporary Algeria (Boyer, 1960, p. 367).

\subsubsection{HOLDING MISSIONARY CONFERENCES}

In some Algerian cities (Constantine: 1924 ...) (Lahmar, 2010, p. 222) , in support of the aforementioned Catholic and Protestant Christian missionary campaigns. 


\subsubsection{BUILDING AN ALTERNATIVE EDUCATIONAL SYSTEM}

That was exclusive then selectively inclusive. It was based on ensuring special education for the French, francization, language hybridization, stirring up racial prejudices, and fighting opponents to do so. This was mainly represented in:

- $\quad$-Setting up educational structures specially for the French: The first College School was built in 1835 (accommodating 36 students) near Al Djenina (downtown); the pace of achievements increased to reach during the Second World War around 1400 schools, according to official statistics for the year 19431944 (Lahmar, 2010, p. 241). The most important ones were: building a high school inaugurated in 1862 that took the name of Bugeaud (started operating in 1868), the National School in 1863, the National School for Teachers in 1865, and the School of Lyon Runnier in 1880 which later turned into the College of Arts, the University of Algeria (between 1888-1909), the High School de la Croix (1908), and the High School "Fromentin" (1944)... In addition, of course, to other French cultural and media institutions reserved to French: libraries, museums, theaters, cinemas and an opera since the 1830's, and whose construction increased after the first wave of mass settlement in 1848 (Laborde, 20/8/2010).

- Distinguishing between Algerians in opening the doors of the French schools to some of them by distinguishing Kabylie region's inhabitants from others. The occupation authorities began implementing this policy from the beginning of 1843 (Lahmar, 2010, p. 197). This regional strife was also encouraged by radio programs, in language and content, after the Second World War.

- -Introducing the French language into the Qur'anic schools, isolating those who rejected it, and deporting them, such as what happened to the Mufti, "Mustafa Kebabti" in 1843, and appointing professors of the colloquial Algerian language in schools (such as the Syrian-Egyptian "Joanny Pharaon") to weaken the Arabic language use.

- Establishment of bilingual (French-Arabic) schools. A decree issued on 6/8/1850 stated the establishment of six French-Arab schools (in some important Algerian cities: Algiers, Constantine, Oran, Annaba, Blida, Mostaganem) (Lahmar, 2010, p. 186).

- The suspension of free seminars in Algerian schools...

- Introducing the Orientalist studies of Arab and Berber dialects in particular, since 1890, and officially sponsoring their books and rewarding their authors, as an expression of a purely political stance to combat Arabic and Islam, and encouraging the distinction between the various components of the Algerian people, especially among the educated ones. (Saadallah, 1998, pp. 19-20).

\subsubsection{BUILDING AN ALTERNATIVE CULTURAL APPARATUS}

as press institutions, libraries, printing press, theaters and cinemas.

\subsubsection{BUILDING A TRIPLE MASS MEDIA SYSTEM}

(press, radio, television) with three journalistic dimensions: outright hostile exclusionary, integrative French and integrative local (publishing from 1830 to 1900 about 150 newspapers). It is well known that radio has taken place since 1929 in the world and television since 1956, but the prevalence in both cases was limited. The content was a glorified propaganda of French civilizational supremacy, an anti-Arab and Islamic civilization affiliation with Algeria, and an encouragement of current Arabic and local dialects.

The catastrophic result of this "emptying and substituting" cultural policy was: a large French communication network in exchange for a sharp decline in the system of Algerian social communication institutions: more than $80 \%$ of the population was illiterate after independence and only about $14 \%$ knew of the rest knew how to read and write, while 1/4 of this percentage were literate in Arabic according to the 1954 census (El Kenz, 1993, p. 21), after that most Algerians were literate, and there were two schools in each Algerian village (Hilal, 1995, p. 108). 
French Memoricides in Algeria: A Study on Socialization Institutions

\section{THE ALGERIAN REACTION}

After the Algerian armed popular resistance, whose pace diminished at the beginning of the twentieth century before it regained its splendor in the 1950s, and despite the financially harsh conditions of occupation and the fight against Arabic calligraphy and Islamic thought in general, some Algerians struggled to draw several ways to preserve their communicative and civilized entity through:

\subsection{WRITTEN RESISTANCE}

Written resistance against French occupation was really prominent by establishing newspapers since 1893 (as: Al- Haqq, al-Misbah, Koukeb Ifriquia, Algeria ...), especially after 1925 with the press of some reformist associations (Association of Scholars, Association of Concord ...) and some Algerian reformers (Ibn Badis, Abu Al-Yaqdhan, Atfiech, Al-Tayyib al-Oqbi, Boukoucheh, Zahiri ...) such as: Al-Mountaqid, Al-chihab, the Ummah, the Maghreb, AlBassair ... that have resisted and did well, especially if we know that their owners did not graduate from journalism schools, but from qura'nic (Katatib) and general educational schools, in addition some of them experienced individual practices in media work inside and outside the country.

In this context, some Algerians have endeavored to write and publish manuscripts in both languages (in the form of books or serial press articles) and in various specializations on the history of Algeria to demonstrate its separate presence from France, in thought and the problems of civilization to show ways of its rise, in literature and biography ...:

In 1907, "Fontana Publishing House" published the first part of the book "Introducing the Ancestor to the Successor" by "Abu al-Qasim al-Hafnaoui" with the release of its second part two years later (1909); and in 1908 the book "The Trip" was published by al-Ouartilani (18 ${ }^{\text {th }}$ century) by Sheikh "Muhammad BenCheneb" (Lahmar, 2010, p. 210); in 1924 Abu Ali al-Zouaoui issued the book "Sermons" in Algeria which included topics revolving around social diseases, ignorance and corruption of morals, in addition to purely religious issues (Al-Mawlid Al Nabawi, Immigration, Fasting, Zakat ...) (Saadallah, 1998, pp. 122-125); and in 1929Sheikh Moubarak Al-Mili published the first part of his book: "History of Algeria in the Old and Modern Age", to support the argument of the existence of his people, their pride and their unity (Lahmar, 2010, p. 225), followed in the same context in 1932 by the publication of the book "The History of Algeria" by "Ahmed Toufiq Al-Madani", which caused a stir because of his revival of the spirit of national excellence and the revival of identity (Lahmar, 2010, p. 228) ... These books were followed by several literary, religious and intellectual publications: "Le Phénomène coranique" by the intellectual "Malek Bennabi", in Paris, who then issued a series entitled "Problems of civilization" including many topics (conditions of renaissance, the problem of culture, and the destiny of the Islamic world ...), And publications of writers and poets: Reda Houhou, Mouloud Feraoun, Muhammad Dib, Moufdi Zakaria ...

In addition, of course, to the establishment of printing presses, which are considered the main contemporary pillar of books, and that was from the late nineteenth century (1896) and thanks to the brothers, "Rodosi" (Keddour and Ali), whose printing became known later as the famous "Thaalibi printing". As for the history of the first Algerian attempt to establish an Arab press, it goes back to the post-First World War, where some Algerians established several printing presses in Algiers, Constantine, Mostaganem, Oran and Biskra in order to print their newspapers and their books and free themselves from their dependence on the French printing. The most important were: the Algerian Islamic printing by Benbadis and the printing of An-Najah (1919) in Constantine; the Arab printing of "Abu Al-Yakdhan" in Algiers (1926), the Al-Balagh press of "Al-Aliouia" in Mostaganem and then in Algiers, the scientific printing of Tayeb al-Oqbi (1929) in Biskra, the Arab Maghreb printing of Hamza Boukoucheh in Oran (1937), and the "Al-Bassair Printing" of the Association of Ulama (1954).

\subsection{RELIGIOUS AND EDUCATIONAL RESISTANCE}

By building some mosques, especially in the countryside, despite the Algerians previous knowledge that they will be taken over by the French authorities (Saadallah, 1998, p. 78); establishing private schools; and activating the cultural, intellectual, and sports associations. The expansion of the reform movement activities since the beginning of the twentieth century reinforced the creation of educational associations and artistic, literary and intellectual clubs in some Algerian cities: the building of "Al-Thaalabya School" in Algiers (1904-1905), establishment of the 


\section{Delliou Foudil}

club of "Nadi Al-taraqqui" in 1919, establishment of sports associations such as the "Al-Tali'a" and the "Mouloudia"in Algiers in 1919, inauguration of "Dar Al-Hadith School" in Tlemcen by Sheikh Al-Bachir Al-Ibrahimi in September 1937... (Mebarkia, 2007, p. 41).

In this context, the Algerian Muslim Scholars Association (since 1931, year of its foundation) has established more than 150 free elementary schools attended by more than 50,000 students to study their language and religion: the "Islamic Youth School" in Algiers, "Educational school" in Constantine, Batna ..., "Al-Irfan" school in Ain Mlila, "Dar Al-Hadith" School in Tlemcen ...

It also created among the migrants (in the colonizer territories), thanks to the activity of Al-Fodil Al-Ouartalani, about thirty centers and cultural clubs, especially in Paris; in Egypt, the Supreme Committee for the Defense of Algeria, the Algerian Community Association and the Association for the Defense of North Africa was formed by some of the descendants of Emir Abdelkader (Saadallah, 1998, p. 500) ...

- Some French cultural symbols were burned, such as what happened to the "Opera" in Algiers in 1871 which was rebuilt to be inaugurated in 1883 (Laborde, 20/8/2010).

\section{CONCLUSION}

Despite acknowledging the serious damage and the destructive and systematic work of the occupation authorities and their settlers, which Algeria suffered greatly from after independence, praise must be given to the resistance work of men who managed to preserve the foundations of the Algerian people's identity and to maintain some of their socialization institutions that enabled them to support an armed revolution (1954-1962) that expelled the occupier after about a century and thirty years of colonial occupation that bled material wealth and aimed at eradicating cultural roots.

In conclusion, the French-Algerian confrontation can be summarized in the wisdom that says: "Who sells the shadow must dispose of his stock before dark," and "Who sells the light must dispose of his stock before dawn breaks

...". This requires from the Algerian authorities, and in particular their legislative institutions - before all else - the double characterization of the French occupier actions in Algeria as war crimes and acts of cultural genocide.

\section{CITATIONS}

1) The original text: "L'exercice de la religion mahométane restera libre; la liberté des habitants de toutes les classes, leur religion, leur commerce et leur industrie, ne recevront aucune atteinte; leurs femmes seront respectées".

2) Ribat: Dedication to "Jihad" and border guards.

3) The names of the printing presses were get from the advertisements of some newspapers of that period, such as the North African Press (from Al-Iqdam newspaper: March the $7^{\text {th }}$ 1919) and Al-Iqdam Press (the same newspaper number of 5/1/1923 ...).

4) The French sources do not mention the number of worshipers killed and injured by the French criminal "Revigo", and only report the version of the son of his translator, "Joanny Pharaon", who estimated the number of protesters at that time to be about 4000 worshipers, and alluded to the injury of some of the protestors as a result of their attempt to escape bullets (Oulebsir, 2004 , p. 88), while it was common in many unofficial Algerian sources to mention the fall of 4000 martyrs whose memory was commemorated by naming the square in front of the mosque "Martyrs' Square". In this work, what was reported was quoted by the Minister of Awqaf and Religious Affairs (Toufiq Al-Madani) just after independence - November 1962 (Rahal, 2018) because the number of 309 martyrs in addition to hundreds of wounded appear to be more real. 


\section{APPENDIX}
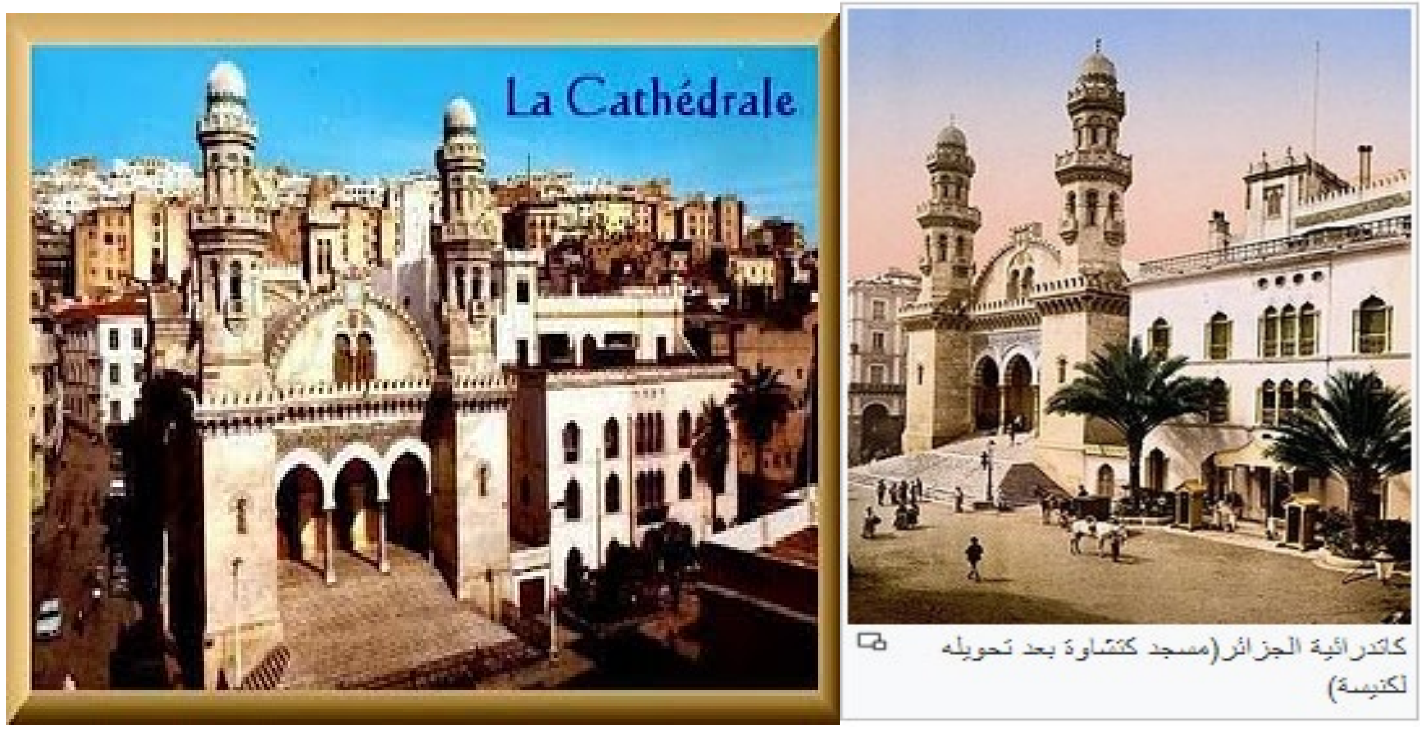

Appendix 1: Photo of Ketchaoua Mosque after its conversion to a cathedral and its inclusion in a postcard during the French occupation

https://fr.wikipedia.org/wiki/Mosqu\%C3\%A9e_Ketchaoua. 24/4/2020

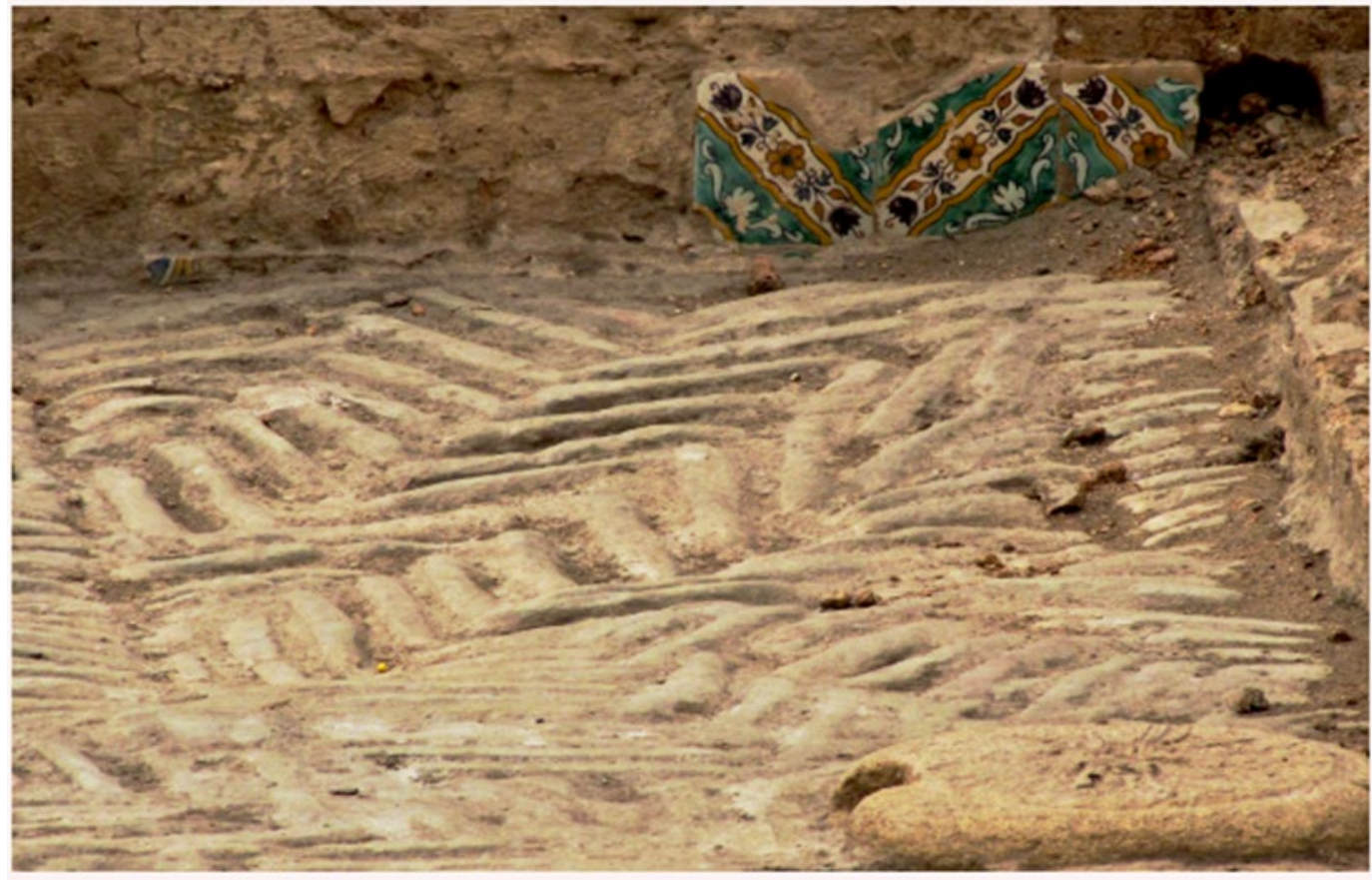

Place des Martyrs, dallage de la mosquée Sayyida, 3 novembre 2018 @MRahal

Appendix 2: The buried ground ruin of the Sayyida Mosque, discovered recently during the excavation work accompanying the construction of the subway in Algiers

Découvert durant le chantier de fouille du Metro d'Alger

Source: Rahal, 02/11/2018 


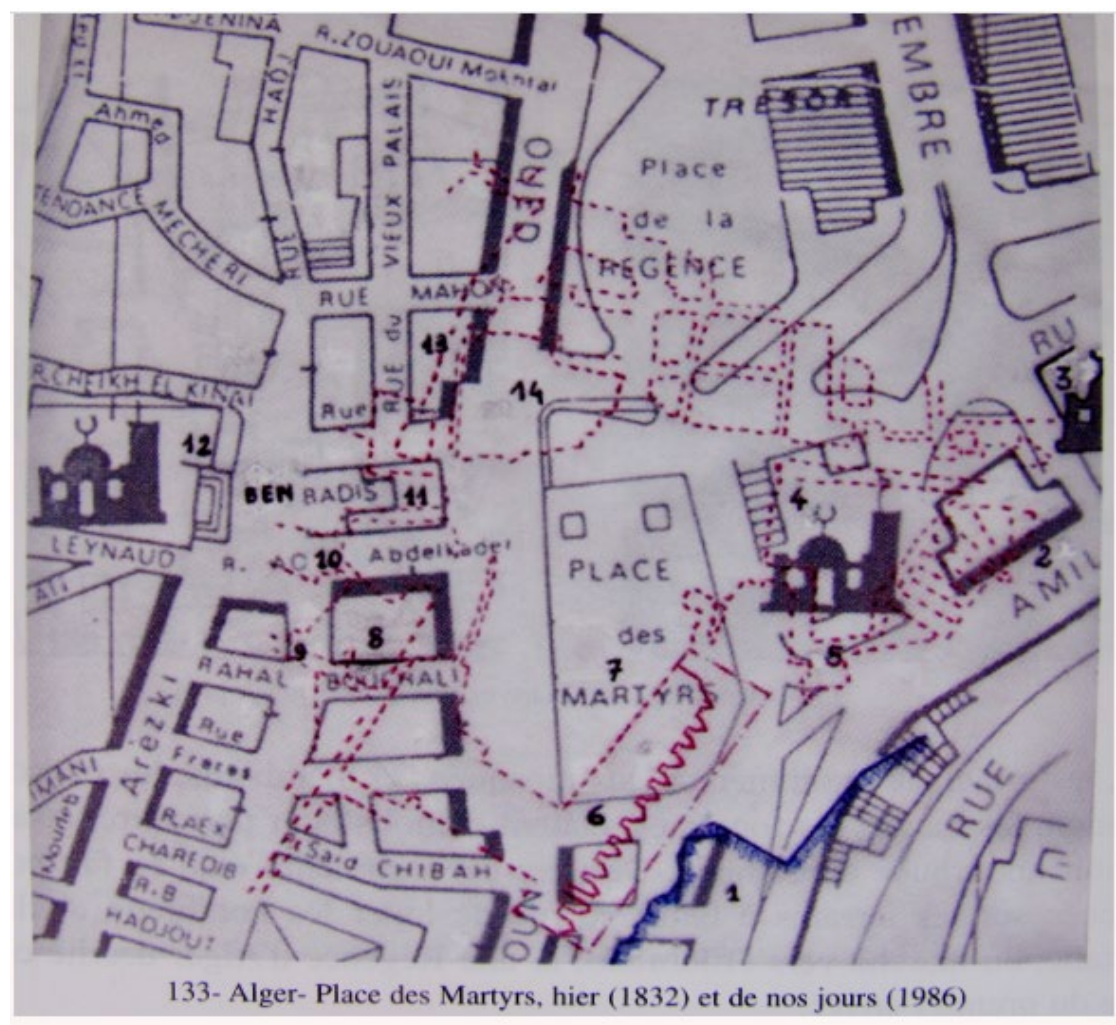

1- La mer 2- Bab al-Bhar 3- Jama'a al-Kabir 4- Jama'a al-Jadid 5- Qa' al-Sur (le has de la muraille) 6-Ratterie de défense 7-I es commerces 8-Place du

Appendix3: A plan drawn by Abdelaziz Ferrah superimposing the city in 1830 on a recent plan makes it possible to measure the extent of the destruction.

Source : https://texturesdutemps.hypotheses.org/3050. Retrieved 28/05/2020

\section{SOURCES OF FUNDING}

This research received no specific grant from any funding agency in the public, commercial, or not-for-profit sectors.

\section{CONFLICT OF INTEREST}

The author have declared that no competing interests exist.

\section{ACKNOWLEDGMENT}

None.

\section{REFERENCES}

[1] Aumerat, M. M. (1898). La Propriété urbaine à Alger, Revue Africaine, Vol.6, N²29-230, pp.168-201. https://gallica.bnf.fr/ark:/12148/bpt6k56907878/f173.image.

[2] Benbennadji Abdennacer (2019). Colonial and Postcolonial Language Policies in Africa: Historical and Emerging Landscapes, Maalim Magazine, Volume 9, p. 12, p. 195-218. From: Marty, Paul (1925). Le Maroc de demain, publication du Comité de l'Afrique Française. Société Générale d'Imprimerie et d'Éditions, Paris, petit in-8, 317 pages.https://www.asjp.cerist.dz/en/article/107746

[3] Al-Hossary, Sati' (1951). Annals of Arab Culture, Riyadh House for Printing and Publishing. 
[4] Blazina, Vesna (1996). Mémoricide ou la purification culturelle: la guerre contre les bibliothèques de Croatie et de Bosnie-Herzégovine. Documentation et bibliothèques, vol. 42 (1996): 149-164. In: bmip.info/articles/Memoricide.pdf 20-6-2012.0r:www.kaka-rigi.net/manu/blazina.htm

[5] Boyer, Ph. (1960). L'Évolution de l'Algérie médiane (Ancien département d'Alger) de 1830 à 1956, Paris: Adrien-Maisonneuve.

[6] Chetouan Belkacem (May 16, 2005). The Impact of the Colonial Project on Spiritual and Educational Institutions in Algeria 1830-1962, Al-Maayar Review, Volume 5, N. 10, p. 391-410. https://www.asjp.cerist.dz/en/article/20357.

[7] Chitour Chems Eddine (1999). L'Éducation et la culture en Algérie. Des origines à nos jours, Alger, ENAG, 1999.

[8] Delliou Foudil (2014). History of the written Algerian press: 1830-2013.Algeria, Dar Houma.

[9] Djeghloul, Abdel Qader (1982). The History of Modern Algeria (Sociological Study), Beirut, Dar Al-Hadatha, p. 2 .

[10] Devoulx M. (Sept. 1862). Les édifices religieux de l'ancien Alger, Revue Africaine, Vol.6, N 35, pp.370382.https://gallica.bnf.fr/ark:/12148/bpt6k5689180t?rk=21459;2

[11] El Kenz Ali (1993).Au fil de la crise, Alger, ENAL.

[12] Feraud, L. Ch. (1868).Les anciens établissements religieux musulmans de Constantine, Revue africaine, vol. $12, \mathrm{~N}^{\circ} 68$ Mars 1868.

[13] Galibert, L. (30/1/2012). L'Algérie ancienne et moderne. https://www.algerieancienne.com/Salon/Galib/8France/01expedit/25capitule.htm. Site consulté le 23/4/2020.

[14] Hilal, Ammar (1995). Research and studies in the history of contemporary Algeria 1830-1962, Algeria: O.P.U.

[15] Laborde, Guy Simon (2010). La Construction d'Alger. www.Storage.canalblog.com/ 87/21/281248/56479359.pdf, 20/8/2010.

[16] Lahmar Kamel: The Algerian society image in (Revue africaine: 1856-1962), PhD thesis, Department of Sociology, University of Constantine, 2010-2011.

[17] Lycops J. P. (1975).L’Agression silencieuse ou le génocide culturel en Afrique, Paris, Anthropos.

[18] Montoy, Louis Pierre (1982). La presse dans le Département de Constantine (1870-1918), Thèse de doctorat d'État, Université de Provence, Institut d'Histoire des Pays d'Outre-Mer, Volume I, 1982.

[19] Oulebsir, Nabila (2004). Les usages du patrimoine : Monuments, musées et politique coloniale en Algérie, Paris: Ed. M.S.H. ISBN 9782735110063. Consulté le 28/5/2020.

[20] Pellegrin, Arthur (2011). Paul Marty: Boufarik 1882, Tunis 1938. http://www.memoireafriquedunord.net/biog/biog14_Marty.htm. 11/05/2020.

[21] Polastron, Deluxe X. (2004). Livres en feu: histoire de la destruction sans fin des bibliothèques. Paris: Denoël.

[22] Rahal, Malika (02/11/2018). Les vies de Ketchaoua, le choc de la conquête et la ville réinventée. https://texturesdutemps.hypotheses.org/3050. Consulté le 28/05/2020.

[23] Saadallah Belkacem (1998). Algeria's Cultural History (Part V), Beirut, Dar Al Gharb Al-Islami.

[24] Saidouni, Nasreddine (1984). Studies and research in the history of Algeria, the Ottoman period, Algeria, the National Book Foundation.

[25] Saidouni Nasreddine (2003). Andalusian studies ..., Beirut, Islamic Dar Al Gharb Al-Islami.

[26] Saadi Othman (1995). The problem of culture in Algeria, Journal of Arts, p. 30, March 1955.

[27] Saaidia Oissila (2016). «L'invention du culte musulman dans l'Algérie coloniale du XIXe siècle », L'Année du Maghreb [En ligne], pp.115-132. 14 | 2016, mis en ligne le 21 juin 2016, consulté le 22 avril 2020. URL: http://journals.openedition.org/anneemaghreb/2689; DOI: https://doi.org/10.4000/anneemaghreb.2689.

[28] Seif al-Islam Zoubir (1985). History of the Press in Algeria, 05 Vol., Algeria, National Book Foundation.

[29] Wikipédia (L'encyclopédie libre). (2018) Mosquée Ketchaoua. https://fr.wikipedia.org/wiki/Mosqu\%C3\%A9e_Ketchaoua. 24/4/2020.

[30] Zaoui Amine (2012). Mémoricide ou autodafé à Alger!, Liberté : 14 juin 2012. 